\title{
SSynthesis
}

International Scientific Conference of IT and Business-Related Research

\section{RAZVOJ SEOSKOG TURIZMA: MOGUĆNOST SUZBIJANJA DEPOPULACIJE U OPŠTINI TRSTENIK}

\section{RURAL TOURISM DEVELOPMENT:}

THE POSSIBILITY OF COMBATING DEPOPULATION IN THE MUNICIPALITY OF TRSTENIK

\author{
Mirjana Dubičanin, Darija Lunić \\ Univerzitet Singidunum, Danijelova 32, Beograd
}

\begin{abstract}
Apstrakt:
Prirodno-geografski i demografski faktori svake pojedinačne oblasti u Republici Srbiji mogu odrediti njene razvojne potencijale. S obzirom na to da se Republika Srbija danas suočava sa demografskom krizom koja preti izumiranju srpskog sela, čiji danak oseća i opština Trstenik koja uprkos svom prirodnom i kulturnom bogatstvu beleži mortalitet veći od nataliteta koji je čak i niži u odnosu na republički prosek za 2001. godinu. Spas u problemu depopulacije ova opština bi trebalo da potraži u razvoju seoskog turizma, tamo gde je prirodna sredina očuvana i čiji bi razvoj i osnovna inspiracija trebalo da bude selo samo po sebi, podizanje njegovog ekonomskog značaja i samostalnosti, zadržavanje mladih na selu, smanjenje stope nezaposlenosti i iskorišćavanje ranije neiskorišćenih kapaciteta. Iz navedenih razloga, seoski turizam trebalo bi posmatrati kao način za rešavanje ili prevazilaženje ovog problema u ruralnim područjima opštine Trstenik.
\end{abstract}

\section{Ključne reči:}

depopulacija, prirodni priraštaj, selo, seoski turizam, ruralna područja.

\section{UVOD}

Pad broja stanovnika u Republici Srbiji, kontinuitet negativnih tendencija i poremećaj osnovnih struktura stanovništva može predstavljati jednu od najznačajnijih i najvećih prepreka u budućem održivom prostornom razvoju Republike Srbije. Glavni problem demografskog razvoja je problem depopulacije u velikim delovima južne, istočne i zapadne Srbije koji je upravo i nastao zbog nepovoljnog nataliteta. Prirodni priraštaj u Republici Srbiji (bez autonomnih pokrajina) i u AP Vojvodini je u stalnom padu, kako u apsolutnom, tako i u relativnom iznosu.

\subsection{DEMOGRAFSKI TRENDOVI I PROJEKCIJE STANOVNIŠTVA}

Shodno poslednjem popisu iz 2011. godine Republika Srbija je imala 7.120.666 stanovnika. U poređenju sa brojem stanovnika na osnovu popisa iz 2002. godine Srbija je imala 7.498.001 stanovnika, što je za 377.335 stanovnika manje u desetogodišnjem međupopisnom periodu.

\section{Abstract:}

Natural-geographical and demographic factors of every particular area in the Republic of Serbia can determine its development potential. The Republic of Serbia nowadays confronts the demographic crisis, whose consequences could also be felt in the municipality of Trstenik. Namely, despite its natural and cultural wealth, this municipality records the death rate which is higher than the birth rate, and even lower than the average national mean value for the year 2001. The Municipality of Trstenik should try to solve the issue of depopulation through advocating rural tourism development in the areas with the preserved nature and it should place an emphasis on the village itself, i.e., increasing its economic importance and independence, keeping young generations in the countryside, decreasing the unemployment rate and using the unexplored resources and capacities. Therefore, rural tourism should be viewed as the way of solving or overcoming such problem in rural areas of the Municipality of Trstenik.

\section{Key words:}

depopulation, natural population growth, countryside, rural tourism, rural areas.

Na broj stanovnika Republike Srbije u vreme popisa iz 2002. godine značajan uticaj je imao priliv velikog broja izbeglih i raseljenih lica koji je iznosio 5,1\% od ukupnog stanovništva Republike Srbije, bez podataka iz AP Kosovo i Metohija. Depopulacija u Republici Srbiji je posebno izražena na opštinskom nivou. Procenat mladih je vrlo nizak i u stalnom je opadanju, dok je procenat starih visok i u stalnom porastu. Po prvi put se beleži veći broj starih nego mladih osoba. Broj lica mlađih od 15 godina je 1.177.000, a broj lica starijih od 65 godina je 1.241.000. Područja koja su posebno ugrožena starenjem i odlivom stanovništva su seoska i brdsko-planinska područja. Stalni pad broja stanovnika u nerazvijenim područjima i nepovoljna starosna struktura dovode do toga da ljudski faktor postaje veliko ograničenje brzog razvoja. Negativne tendencije demografskog faktora su u direktnoj vezi i sa lošom privrednom razvijenošću ovih područja i visokom stopom nezaposlenosti koja je u 2008. godini iznosila 49,3\%. Ovaj složeni sistem uzročno-posledičnih veza i efekata koji postepeno prelazi u ozbiljnu prepreku ukupnog razvoja Republike Srbije zahteva posebnu posvećenost politici o stanovništvu i precizno određivanje sredstava za njeno aktivno 


\begin{tabular}{|c|c|c|c|c|c|c|c|}
\hline God. & 1953 & 1961 & 1971 & 1981 & 1991 & 2002 & 2011 \\
\hline Stan. & 6.979 .154 & 7.642 .227 & 8.446 .511 & 9.313 .676 & 9.778 .991 & 7.498 .001 & 7.120 .666 \\
\hline
\end{tabular}

Tabela 1. Broj stanovnika u Republici Srbiji prema rezultatima popisa iz 1953, 1961, 1971, 1981, 1991, 2002 i 2011. godine. Izvor: RZS

sprovođenje. Osnovne karakteristike stanovništva i tendencije demografskog razvoja predstavljaju važnu odrednicu društveno-ekonomskog razvoja, planiranja i organizacije prostora (Ministarstvo građevinarstva, saobraćaja i infrastrukture, 2010).

Veliki problemi sa kojima je Republika Srbija ušla u XXI vek su: širenje depopulacionih prostora, nedovoljno obnavljanje stanovništva, duboko ukorenjene niske reproduktivne norme, odlaganje rađanja, visoka psihološka i ekonomska cena roditeljstva, odsustvo reproduktivnih potencijala na određenim teritorijama što sprečava njihovu revitalizaciju. Prirodni priraštaj u centralnoj Srbiji je negativan od 1992. godine, dok je u isto vreme povećan broj lica na radu i boravku u inostranstvu, tako da je 2002. godine registrovano oko 415.000 lica na radu i boravku u inostranstvu. Ako Republika Srbija uskoro postane članica Evropske unije, to može imati presudan uticaj na smer $\mathrm{i}$ intenzitet spoljnih migracija i dovesti do bitnih promena $\mathrm{u}$ poređenju sa prethodnim periodom. Nasuprot tome, znatno se smanjuju mogućnosti promene aktuelne tendencije neto migracionog bilansa i predviđa se dalji trend negativnog migracionog obrasca. Verovatnoća da će Republika Srbija 2020. godine imati više stanovnika nego danas je oko $15 \%$ prema optimističkom scenariju, tj. potpunoj realizaciji strategije podsticanja rađanja (Ministarstvo građevinarstva, saobraćaja i infrastrukture, 2010). Potrebno je razvijati emigraciona i nedovoljno razvijena područja i obezbeđivati uslove za povratak stanovništva. Područja kvalitetne životne sredine kao što su šumska područja, turističke zone kontrolisanog razvoja, poljoprivredne voćarske i vinogradarske zone, područja sa prirodnom degradacijom, livade i pašnjaci i područja sa preovlađujućim pozitivnim uticajima na čoveka, živi svet i kvalitet života su područja za koja treba obezbediti rešenja koja mogu eliminisati ili smanjiti postojeće izvore negativnih uticaja. Dosadašnja razvojna kretanja uzrokovala su to da je na skoro $90 \%$, teritorije gde živi oko polovina stanovništva, moguće konstatovati snažnu depopulaciju i nepovoljnu demografsku strukturu, slabo razvijenu privredu i znatno slabiju infrastrukturnu opremljenost nego u urbanim područjima. Ipak, intenzitet i karakteristike strukturnih promena u selima i ruralnom prostoru Republike Srbije, kao i njegov značaj za ukupni i ravnomerni teritorijalni razvoj zemlje, obavezuju da obnova i uređenje ruralnih područja i sela, na održiv i društveno racionalan način, budu jedan od osnovnih strateških prioriteta Republike Srbije.

\section{EKONOMSKI EFEKTI RURALNOG TURIZMA}

Oko 85\% teritorije Republike Srbije spada u ruralno područje sa oko 4.800 sela, a procenjuje se da će mala sela, koja se najviše nalaze u istočnoj, jugoistočnoj i južnoj Srbiji za manje od dve decenije izgubiti stalne stanovnike. U ovim oblastima živi oko 55\% stanovništva Republike Srbije, a prosečna gustina naseljenosti iznosi 63 st/ha. U ruralne oblasti, na osnovu OECD (Organisation for Economic Cooperation and Develpopment) klasifikacije spadaju oblasti gde je gustina naseljenosti manja od $150 \mathrm{st} / \mathrm{km}^{2}$, dok po kriterijumu EU u ruralne oblasti spadaju mesta sa gustinom naseljenosti manjom od $100 \mathrm{st} / \mathrm{km}^{2}$. Turistički resursi Republike Srbije nisu dovoljno valorizovani. Njihovo učešće u BDP-u je ispod 2\% (Ministarstvo građevinarstva, saobraćaja i infrastrukture, 2010). U ponudi Republike Srbije nedostaju raznovrsniji turistički proizvodi koji bi mogli da privuku inostranu tražnju, posebno na kulturnim i ekološkim motivima. Nedovoljno su afirmisani koncept održivog turizma i njegova integracija sa komplementarnim privrednim delatnostima kao i sa prirodnim i kulturnim nasleđem. Ruralni turizam se doživljava kao važan pomoćni privredni sektor koji će unaprediti i osigurati održivi razvoj ruralnih zajednica. Glavni cilj seoskog turizma je obezbeđivanje dodatnog prihoda seoskom stanovništvu, objedinjavajuci niz turističkih atrakcija, usluga i sekundarnih aktivnosti koje ruralno stanovništvo i privatna domaćinstva pružaju. Strategija razvoja turizma podržava promociju i razvoj seoskog turizma i direktno doprinosi uspostavljanju ravnoteže celokupnog ekonomskog razvoja zemlje, kao i smanjivanju nejednakosti u raspodeli resursa izmedu urbanih i ruralnih područja. Ruralni turizam se ocenjuje kao još uvek nedovoljno strukturiran i organizovan. U programu konkurentnosti i predloženim akcionim planovima nisu navedeni programi ili akcioni planovi koji bi se ticali direktno ruralnih područja. Pozitivni trendovi koje donosi seoski turizam su bolje zapošljavanje žena, zadržavanje mladih na selu, iskorićšćavanje ranije neiskorišćenih kapaciteta, nova radna mesta i bolji odnos lokalnog stanovništva prema životnoj sredini (Ministarstvo trgovine, turizma i telokmunikacija, 2006).

Očekivanje da turizam doprinese bržem razvoju i revitalizaciji ruralnih područja Srbije temelji se na mogućim ekonomskim efektima od razvoja ove delatnosti. Prema mišljenju Medlika (1966) turizam ima direktne efekte na one učesnike ponude koji direktno prodaju usluge turistima. U slučaju ruralnog turizma to su, pre svega, seoska turistička domaćinstva. Razvoj turizma pruža mogućnost seoskim domaćinstvima da uz minimalne investicije zaposle članove svog domaćinstva i obezbede dodatni izvor prihoda. Takođe, bavljenje ovom delatnošću pruža mogućnost da seoska domaćinstva ostvare prihode i od plasmana proizvoda iz domaće proizvodnje kao što su poljoprivredni proizvodi i proizvodi domaće radinosti. Prema rezultatima anketnog istraživanja koje je 2009. godine objavilo Ministarstvo poljoprivrede, šumarstva i vodoprivrede Srbije, ruralni turizam u proseku zapošljava dva člana domaćinstva, a prosečan mesečni neto prihod od bavljenja ruralnim turizmom po domaćinstvu iznosi oko 200 evra (Bošković, 2012). Važno je naglasiti da razvoj ruralnog turizma može doprineti i ekonomskom osnaživanju ruralne populacije. Imajući u vidu veliku zavisnost ruralne ekonomije od poljoprivrede, značajna je činjenica da razvoj ruralnog turizma prvenstveno podstiče razvoj poljoprivredne delatnosti u ruralnim područjima. Procene efekata ruralnog turizma na razvoj ukupne ekonomije Srbije iznete su u najnovijem strateškom dokumentu u nacionalnom Master planu za razvoj seoskog turizma u Srbiji. Prema podacima iz Master plana ukupan broj ležaja u ruralnim područjima godišnje generiše više od 5.000.000.000 dinara prihoda od smeštaja i sa oko 5.000.000.000 dinara doprinosi većim direktnim prihodima u sektoru turizma. Takođe, prema predviđanjima prihod od turizma će u narednih 5 godina, do 2020. godine, dostići 45.000.000.000 dinara. Naravno, pretpostavke za ostvarenje ovih predviđanja su povećanje broja posetilaca, broja noćenja u ruralnim oblastima, kao i tražnje za ruralnim smeštajnim kapacitetima u budućem periodu (UNWTO \& Tourism \& Leisure Advisory Services, 2011). Ruralni turizam se oslanja prvenstveno na domaću tražnju iz urbanih područja tako da bi njegov intenzivniji razvoj mogao da doprinese prelivanju dohotka iz 
privredno razvijenijih urbanih regiona u nedovoljno razvijena ruralna područja. Tako bi turizam doprineo bržem privrednom razvoju ruralnih oblasti što bi uticalo na smanjivanje postojećeg jaza u razvoju ruralnih i urbanih područja.

\section{TURISTIČKI POTENCIJAL OPŠTINE TRSTENIK}

Ruralna područja Zapadnog Pomoravlja i opštine Trstenik karakteriše velika poljoprivredna struktura, intenzivna poljoprivredna proizvodnja voća, povrća i proizvoda životinjskog porekla, ali i bogat turistički potencijal. Razvoj ruralnog turizma povezuje se sa drugim oblicima turizma - obnova tradicionalnog seoskog domaćinstva, dogradnja i adaptacija objekata, oživljavanje starih zanata i promotivne aktivnosti. Trstenik se nalazi u centralnom delu Srbije, 205 kilometara južno od Beograda. Područje opštine Trstenik zahvata površinu od $448 \mathrm{~km}^{2}$. Nalazi se u dolini reke Zapadne Morave, na njenoj desnoj obali i obroncima planine Goč i Gledićkih planina. Gledićke planine se smatraju najlepšim šumadijskim planinama zbog velikih prirodnih lepota: klisurastih dolina, planinskih rečica i potoka, brojnih izvora i bogatog biljnog sveta. Nazivaju ih još i mitskim planinama jer čuvaju tragove od najstarijih vremena, od neolita preko sedam srednjovekovnih gradova sagrađenih na rimskim utvrđenjima. Grad Trstenik nalazi se na $21^{\circ}$ istočno od Griniča, $43,5^{\circ}$ severne geografske širine i na sto osamdeset prvom metru nadmorske visine, dok se nadmorska visina opštine kreće od 160 metara u dolini Zapadne Morave do 922 metra na vrhu Gledičkih planina. U Trsteniku vlada umereno-kontinentalna klima sa blagim zimama i prijatnim letima. Arheološki lokaliteti opštine Trstenik koji svedoče o tome da je čovek još iz perioda Neolita, pre oko 8.000 godina, prepoznao potencijal ovog područja i izabrao ga da se na njemu nastani su Blagotin i Stragari. Herodot je pisao da uz reku Angnos (Zapadna Morava) leži tribalska ravnica naseljena plemenima Tribali. Oni su područje Trstenika naseljavali oko V veka pre nove ere. Arheološki lokalitet Stražba datira iz vremena Rimljana i jasno svedoči o tome kako su Rimljani u ove krajeve doneli i počeli da uzgajaju vinovu lozu. Rimljani su ove prostore osvojili oko I veka nove ere i tada su delom istrebili, delom asimilovali i delom potčinii lokalno stanovništvo, postavši pritom dominantna sila celog podneblja. Iz rimskog perioda potiče kastrum na Stražbi i arheološka nalazišta u selima Bučje i Donji Dubič. Prvi pisani pomen Trstenika nalazi se u darovnoj povelji manastiru Ravanici, kojom knez Lazar 1381. godine svojoj zadužbini poklanja metohe Trstenik, Veluće i Ribnik. Povelja se čuva u biblioteci u Bolonji. Iz srednjovekovnog perioda potiču i manastiri moravske arhitektonske škole, Ljubostinja i Veluće. Manastir Veluće se nalazi između sela Veluće i sela Riđevštica, na sredini puta Kruševac - Trstenik. Manastir je posvećen Vavedenju Presvete Bogorodice. Podignut je 1377. ili 1378. godine i zadužbina je nepoznate vlastelinske porodice. Oko 1389. godine nepoznati ktitor je ovaj hram poklonio ruskom manastiru Sveti Pantelejmon na Svetoj Gori kada crkva dobija živopis. U neposrednoj blizini manastira na teritoriji sela Veluće i Tobolac nalaze se izvori mineralne vode koji su od davnina poznati po svom lekovitom dejstvu, pa se manastir Veluće često pominje kao "izvorska građevina”. Vredni kulturno-istorijski spomenici su i crkva Svetog Arhangela Gavrila u Gornjem Ribniku i crkva Svete Petke na Grabovačkom brdu. U prvoj polovini XV veka Turci su došli do ovih prstora. Osvojili su Kruševac i u tom periodu započela je izgradnja pograničnih utvrđenja među kojima je najpoznatiji bio Grabovac ili Jerinin grad. Za Jerinin grad vezane su mnoge legende. On je smešten na obali Zapadne Morave, na mestu gde su padine Goča i Gledićkih planina najbliže i oduvek je privlačio pažnju kako istraživača tako i običnog naroda. Jerinin grad je od Vrnjačke Banje udaljen svega $5 \mathrm{~km}$. Arheološka istraživanja Grabovca počela su 2010. godine, tako da će se o njegovoj sada malo znanoj prošlosti u narednim godinama znati mnogo više. Sela Trstenika prava su oaza za sve ljubitelje seoskog turizma i odmora u prirodi. Netaknuta priroda, tradicionalni običaji, stari zanati, prostrani vinogradi i voćnjaci, kvalitetna vina i ukusna hrana trsteničkih sela. Veluće, Brezovica, Ribnik ili Bučje osvajaju pri prvom susretu. Sela sa leve strane Zapadne Morave, Medveđa, Velika Drenova i Milutovac čuvena su po proizvodnji voćnih i loznih kalemova. Za ljubitelje prirode i aktivnog odmora u trsteničkoj opštini postoje markirane planinarske staze na Gledićkim planinama i Goču u dužini preko 100 kilometara. Ljubitelji prirode i pešačenja mogu upoznati vrhove okolnih planina, izabrati ili stazu kneginje Milice gde će poći stopama srpske vladarke i ktitora manastira Ljubostinja ili stazu Starih zanata koja vodi dolinama Popinske reke i Bršljanice. Sakupljanje lekovitog bilja, pečuraka i šumskih plodova je takođe jedna od aktivnosti koja se nudi gostima na selu. Lov u trsteničkoj opštini takođe ima dugu tradiciju. Tokom srednjeg veka ovaj kraj je bio lovište vlastele gde je lovio i sam knez Lazar. Lovište Dubičke reke ima površinu od $448 \mathrm{~km}^{2}$ i udruženje ima 1.700 članova. U neposrednoj blizini Trstenika, oko dva kilometra istočno od centra, nalazi se turističko-sportski aerodrom “Trstenik" za koji stručnjaci kažu da je jedan od najpogodnijih aerodroma u zemlji za raznolike vazduhoplovne aktivnosti i potrebe. Ovaj aerodrom i Aero-klub "Trstenik" organizuju panoramsko razgledanje grada i okoline i škole letenja, jedriličarstva, modelarstva i padobranstva (Lokalni akcioni plan opštine Trstenik, 2010).

\subsection{STANOVNIŠTVO I DEMOGRAFSKA KRETANJA U OPŠTINI TRSTENIK}

Prema popisu stanovništva iz 2011. godine na teritoriji opštine Trstenik, na površini od $448 \mathrm{~km}^{2}$, živi 42.989 stanovnika, što je za 6.054 stanovnika manje u odnosu na podatke iz popisa stanovnika iz 2002. godine koji je iznosio 49.043, sa prosečnom gustinom naseljenosti od $109 \mathrm{st} / \mathrm{km}^{2}$. Stanovništvo živi u $51 \mathrm{na}-$ seljenom mestu koja su raspoređena u 31 mesnoj zajednici. Na teritoriji opštine, shodno podacima iz popisa iz 2011. godine, postoji ukupno 14.662 domaćinstva, dok je broj domaćinstava 2002. godine bio 16.080 (grad 6.215, selo 9.865). Na području današnje opštine Trstenik 1948. godine živelo je 43.473 stanovnika, 1981. godine bilo je 53.695 stanovnika i 1991. godine 52.796 stanovnika. Devedesetih, a naročito početkom dvehiljaditih godina broj stanovnika je drastično opao, što je posledica niskog, ali i negativnog prirodnog priraštaja. Prirodni priraštaj u opštini Trstenik za 2002. godinu iznosio je $-6,6 \%$, što u apsolutnom iznosu znači da je mortalitet veći od nataliteta za 321 stanovnika, što je niže i u odnosu na republički prosek za 2001. godinu $(0,4 \%)$. Opadanje nataliteta, odnosno prirodnog priraštaja, posledica je migracije na relaciji selo-grad i prvenstveno posledica odliva mlade populacije u veće gradske sredine $\mathrm{i}$ inostranstvo, što je posledica sve veće nezaposlenosti i opadanja životnog standarda. Opadanje prirodnog priraštaja doveo je do poremećaja u starosnoj strukturi, kao i do intenzivnih promena u socio-ekonomskoj strukturi. Prosečna starost u opštini Trstenik iznosi 42,2 i to 43,3 kod žena i 41,0 kod muškaraca (Republički zavod za statistiku, 2013).

Alarmantni podaci iz poslednjeg popisa stanovništva ukazuju na nestanak brdskih sela u trsteničkoj opštini i njihovo potpuno napuštanje. Zabrinjavajuće razlike iz poslednja dva popisa u broju stanovnika trsteničkih sela kao što su Bučje, Veluće, Gornji Dubič, Donji Dubič, Dublje, Brezovica, Jasikovica, Okruglica, Pasjak, Planinica, Popina, Rajinac i Stublica bi se 


\begin{tabular}{|c|c|c|c|}
\hline Godina & Broj stanovnika & Apsolutni porast/pad & Porast/pad broja stanovnika u \% \\
\hline 1948. & 43.473 & -2.232 & -5 \\
\hline 1953. & 46.675 & 3.202 & 7 \\
\hline 1961. & 49.209 & 2.534 & 5 \\
\hline 1971. & 50.776 & 1.567 & 3 \\
\hline 1981. & 53.695 & 2.919 & 6 \\
\hline 1991. & 54.873 & 1.178 & 2 \\
\hline 2002. & 49.043 & -5.830 & -11 \\
\hline 2011. & 42.989 & -6.054 & -13 \\
\hline
\end{tabular}

Tabela 2. Kretanje broja stanovnika u opštini Trstenik od 1948 - 2011. god.

Izvor: RZS

trebalo zaustaviti i smanjiti kako bi se ova sela ponovo oživela i podmladila. Veliki odliv stanovnika u veće gradove iz trsteničkih sela i iz samog grada, koji poslednjih godina doživljava i koji se suočava sa privrednom nerazvijenošću i velikom nezaposlenošću, mogao bi se smanjiti i delimično sprečiti razvojem seoskog turizma u selima opštine Trstenik čiji geografski položaj i prirodna bogatstva nude rešenja gašenja ognjišta i izumirnja sela u kojima bi boravak turista mogao promeniti živote njihovih stanovnika. Shodno popisnim rezultatima iz 2002. godine i 2011. godine u proseku je svako gore navedeno selo u trsteničkoj opštini napustilo 67 stanovnika. Broj popisanih stanovnika je veoma nizak i ukoliko se odlivanje stanovnika bude nastavilo ovim intenzitetom, u skorijoj budućnosti, ova mesta će postojati samo na geografskim mapama. Ova sela Trsteničke opštine su prava oaza za sve ljubitelje seoskog turizma i odmora u prirodi. Netaknuta priroda, tradicionalni običaji, stari zanati, prostrani vinogradi i voćnjaci, kvalitetna vina i hrana osnovna su karekteristika trsteničkih sela. Sela čija pozicija, prirodna i kulturna bogatstva poseduju potencijal za razvoj seoskog turizma su Brezovica, Bučje, Veluće, Gornji Dubič, Donji Dubič, Dublje, Jasikovica, Okruglica, Pasjak, Planinica, Popina, Rajinac i Stublica.

Ova sela trsteničke opštine koja su pogođena demografskom krizom i velikim smanjenjem broja stanovnika iz decenije u deceniju, kao što je i prikazano u tabeli, spas bi trebalo da traže u razvoju ruralnog turizma. Ruralni turizam i razvijanje svesti lokalnog stanovništva o važnosti i mogućnostima koje ova delatnost nudi ovom kraju bi se mogle oceniti kao pozitivna tačka u budućem periodu.

\subsection{RAZVOJNE MOGUĆNOSTI SEOSKOG TURIZMA U OPŠTINI TRSTENIK}

Turizam je jedna od prepoznatih šansi za zapošljavanje stanovnika opštine Trstenik. Međutim, osim prirodnih lepota i istorijskog nasleđa, neophodno je i konkretno ulaganje u ovu oblast da bi se obezbedio veći broj turista i povećala njihova potrošnja. Ovaj sektor u kome ima mnogo prostora za unapređenje može uticati i na poboljšanje rada u drugim sektorima, pre svega u poljoprivredi. Sela trsteničke opštine smeštena na šumovitim padinama Goča i Gledićkih planina predstavljaju odličan potencijal za razvoj seoskog turizma. Listopadne šume, čiste planinske rečice, prostrane livade obrasle lekovitim biljem i ekološki zdrava sredina čine ambijent atraktivnim. Ovome treba dodati i tradicionalno gostoprimstvo lokalnog stanovništva, mogućnost za rekreaciju u prirodi kao što su sakupljanje lekovitog bilja, pečuraka, plodova divljeg voća, obavljenje seoskih poslova i uživanje u domaćim specijalitetima hrane i pića. Selo Brezovica se nalazi na desnoj obali Zapadne Morave, na brežuljkastim padinama šumovite planine Goč (Mali Vrh - 992 m). Selo je razbijenog tipa sa $42.8 \%$ agrarnog stanovništva. Udaljeno je $12 \mathrm{~km}$ od Trstenika i isto toliko od Vrnjačke Banje, tako da ima odličan geografski položaj. Samo selo preseca Brezovička reka koja stvara živopisnu dolinu. Brežuljkast reljef, umerenokontinentalna klima, vijugav tok Brezovičke reke, brze planinske rečice, šumski kompleksi koji se smenjuju sa vinogradima i oranicama, raznolik biljni i životinjski svet čine ovaj krajolik veoma zanimljivim. Po predanju naziv sela je biogeografskog

\begin{tabular}{|c|c|c|c|c|c|c|c|c|c|}
\hline \multirow{2}{*}{$\begin{array}{l}\text { Red. br. } \\
\text { God. br. }\end{array}$} & \multirow{2}{*}{ naselje } & \multicolumn{7}{|c|}{ Broj stanovnika } & \multirow[b]{2}{*}{2011} \\
\hline & & 1948. & 1953. & 1961. & 1971. & 1981. & 1991. & 2002. & \\
\hline 1 & Brezovica & 860 & 857 & 910 & 880 & 869 & 781 & 636 & 575 \\
\hline 2 & Bučje & 765 & 720 & 427 & 401 & 579 & 592 & 458 & 275 \\
\hline 3 & Veluće & 423 & 453 & 453 & 459 & 482 & 489 & 417 & 375 \\
\hline 4 & G.Dubič & 313 & 296 & 287 & 212 & 199 & 149 & 109 & 79 \\
\hline 5 & D.Dubič & 291 & 300 & 293 & 274 & 243 & 258 & 214 & 182 \\
\hline 6 & Dublje & 785 & 630 & 648 & 572 & 587 & 539 & 492 & 449 \\
\hline 7 & Jasikovica & 983 & 1032 & 1021 & 900 & 905 & 840 & 670 & 581 \\
\hline 8 & Okruglica & 401 & 393 & 397 & 346 & 359 & 319 & 261 & 219 \\
\hline 9 & Pajsak & 149 & 144 & 150 & 134 & 155 & 120 & 84 & 64 \\
\hline 10 & Planinica & 404 & 402 & 399 & 339 & 279 & 222 & 198 & 167 \\
\hline 11 & Popina & 520 & 548 & 504 & 496 & 466 & 433 & 384 & 329 \\
\hline 12 & Rajinac & 607 & 608 & 608 & 526 & 403 & 303 & 233 & 136 \\
\hline 13 & Stublica & 329 & 350 & 337 & 293 & 282 & 236 & 210 & 61 \\
\hline
\end{tabular}

Tabela 3. Kretanje broja stanovnika opštine Trstenik po naseljenim mestima pogodinim za razvoj seoskog turizma za period 1948 - 2011. Izvor: RZS 
porekla po prostranim brezovim šumama, iskrčenim u vreme osnivanja sela. Današnje selo Brezovica se prvi put spominje 1476. godine u turskim tefterima pod nazivom Stanci i pripadalo je opštini Vrnjci. Selo Brezovica ima 781 stanovnika i 213 domaćinstava i spada u jedno od manjih seoskih naselja u opštini Trstenik. Prosečna gustina naseljenosti je ispod $100 \mathrm{st} / \mathrm{km}^{2}$. Kako je dolina Brezovačke i Popinske reke veoma bogata mermerom, stanovništvo se uglavnom više od dva veka bavi krečarskim zanatom. Osim krečarstva, meštani kao svoje osnovne poljoprivredne potencijale pre svega ističu nezagađenu životnu sredinu za proizvodnju biološki zdrave hrane (maline, kupine, šljive). U selu postoji crkva Svete Petke koja je izgrađena 1874 godine kao crkva-brvnara koja je služila svojoj nameni sve do 1931. godine kada je na njeno mesto sagrađena savremena crkva Svete Petke. Legenda kaže da je ovuda prolazio stari karavanski put koji je vodio preko Župe za Niš i da su prolazeći ovuda car Konstantin i carica Jelena na obližnjem izvoru "Krštena voda" primili hrišćansku veru. Izvor "Krštena voda" se nalazi u podnožju planine Vratarne koju pominje Milovan Glišić u svojoj pripovetki "Prva brazda". Posebno mesto u selu Brezovica zauzima razvoj seoskog turizma, povoljan geografski položaj, raznolik reljef i prijatna umereno-kontinentalna klima, očuvana životna sredina, bogatstvo voda, kulturno-istorijski spomenici u okruženju, etnografsko nasleđe, poznata predusretljivost ljudi i neiscrpne mogućnosti u poljopruvredi su više nego dobra osnova za razvijanje seoskog turizma. Celo područje je idealno za pešačenje, biciklizam, planinarenje i lov. Bogatstvo prirode, šuma i pašnjaka pogoduju prikupljnju lekovitog bilja i pečuraka što bi u perspektivi mogao da bude veliki potencijal sela. $\mathrm{Na}$ početku i na kraju sela nalazi se po jedna vodenica potočara. U jugozapadnom delu sela nalazi se skretanje za susedno selo Stublice u kom se nalazi kamenolom (majdan) iz koga se vadi kamen krečnjak. Krečane su raspoređene duž asfaltnog puta i ima ih oko 20-ak od kojih su samo nekoliko aktivne. U selu ima dosta voćnjaka gde dominiraju malinjaci, a po obodu sela nalaze se šume (brezove, bukove hrastove, a ima i četinara) koje se prostiru na 529 ha, dok 186 ha otpada na njive. Voćnjaka ima nešto manje 152 ha, dok se pašnjaci prostiru na 99 ha. U selu su zastupljeni stari zanati koji odolevaju novom dobu. Jedan od njih je izrada vodenica potočara. Ovaj stari zanat je nekada bio veoma rasprostranjen. Vodenice su sagrađene početkom i u prvoj polovini XX veka. U Brezovici je nekada bilo 18 vodenica potočara. Nažalost, danas su u funkciji samo dve i u njima se povremeno pokrene vodenički kamen kako bi stari vodeničar samleo brašno. Desetak okolnih sela trsteničke i aleksandrovačke opštine ovde je svakodnevno mlelo brašno, a danas je malo onih koji žele da osete ukus prošlih vremena i starinske pogače. U Brezovici danas ima oko 30 krečana od kojih samo nekoliko aktivno peku kreč. Brezovica raspolaže sa 19 ležajeva u tri domaćinstva (osam dvokrevetnih i jedna trokrevetna) sa mogućnošću proširenja. Turističko-ugostiteljska kuća "Brezovica" je nosilac seoskog turizma u selu Brezovica, kao i u opštini Trstenik, čiji je vlasnik porodica Glidžić koja se od 1991. godine uspešno bavi seoskim turizmom. Turističko ugostiteljska kuća "Brezovica" raspolaže sa tri dvokrevetne i jenom trokrevetnom sobom (na dve sobe jedno kupatilo) i prijatnim restoranom koji ima kapacitet da u jednom momentu ugosti 30 gostiju. U letnjem periodu izuzetno je atraktivan bazen za kupanje koji je napravljen još 1967. godine kao okosnica seoskog turizma, poluolimpijskih razmera koji se puni izvorskom vodom, okružen zelenilom koje upotpunjuje lepotu pejzaža, tako da u letnjim mesecima veliki broj meštana kao i gostiju spas od visokih tempetarura traže u njemu. Ugostiteljska kuća "Brezovica” ugostila je stotine porodica, kako iz zemlje tako i iz inostranstva i svi su bili oduševljeni lepotama ovog sela. Najveći promet zabeležen je 2002. godine kada je ostvareno 500 noćenja. Ponudu turistič- ko-ugostiteljske kuće "Brezovica" upotpunjuje i etno- muzej u kome je postavka starih predmeta, a posetioci sela Brezovice mogu kupiti i sa sobom poneti suvenire, kao što su razne vrste slatka, rakije, likera, vunene čarape, vuneni prsluci i ostale proizvode koje su proizveli domaćini i domaćice sela Brezovica. Etno-selo "Rakezić" je projekat novijeg datuma. Nedavno je 18 domaćina osnovalo udruženje pod nazivom "Domaćini sela Brezovica" koje preuređuje deset hektara imanja na oko 500 metara nadmorske visine u etno turistički kompleks. Rakezić je kupio veći broj starih brvnara i u budućem etno-selu izgradiće restoran sa 12 kuća koje će imati ukupno 25 ležajeva za goste. Brezovčani se maksimalno trude da stvore zanimljive sadržaje kako gostima boravak na selu ne bi bio dosadan i nadaju se da će svake godine njihov broj biti znatno veći i da će turisti koji budu posećivali Vrnjačku Banju i Manastir Ljubostinja biti dragi gosti Brezovčana. Tu su i Ozonske staze - starih zanata pa svi ljubitelji planinarenja, ali i oni koji vole stare zanate, ovde mogu provesti prijatne trenutke (Vukčević, 2009).

Selo Popina kroz koje protiče Popinska reka je po podacima podacima iz 2011. godine imalo 329 stanovnika, rasporedjenih u 105 domaćinstava. Poznato je po obilju kvarcitnog kamena i njegovoj obradi. U radionici za estetsko oblikovanje kamena iz 1935. godine inspiraciju nalaze u kamenoj plastici moravske škole. U selu Dublje prema podacima iz popisa iz 2011. godine živi 449 stanovnika u 146 domaćinstava. Ime sela, po predanju, potiče od velikih komada kamenih gromada - dubova u čijoj je blizini i selo nastalo. Kamen iz ovog sela, "dubljanski kamen" iz okolnih majdana poznat je i van granica Srbije. Nekoliko porodičnih radionica se i dalje bavi klesanjem mlinskih kamenova. Najstarija kamenorezačka radnja datira iz 1875. godine, iz takozvanog "zlatnog doba kamenorezaca", kada su se vodenice nalazile na svakom potoku.

$\mathrm{Na}$ mestima nekadašnjih rimskih, a potom i carskih vinograda na području sela Jasikovica i Bučje danas niču novi zasadi vinove loze koja daje vina odličnog kvaliteta. Blogorodni proplanci sela Bučje u blizini manastira Veluće i sela Jasikovica sa svojim vinogradima čuvaju tradiciju vina i vinskih puteva ovog kraja. Selo Jasikovaica danas ima 581 stanovnika, a selo Bučje 275 stanovnika prema poslednjem popisu iz 2011. godine. Veliko smanjenje broja stanovnika u odnosu na 2002. godinu treba zaustaviti podsticanjem meštana da koriste prirodne potencijalne koje ova sela poseduju. U poslednje vreme se organizuje likovna kolonija i dovode gosti što bi trebalo da motiviše stanovnike da se organizuju i ozbiljnije pristupe razvoju seoskog turizma. Na nedavno održanom 20. Saboru narodnog stvaralaštva "Zlatne ruke Srbije" u Vrnjačkoj Banji u organizaciji Turističke organizacije Srbije prvo mesto u kategoriji stari zanati i suveniri osvojila je Turistička organizacija opštine Trstenik kojoj je ovo prvi nastup na tradicionalnom Saboru. Opštinu Trstenik je predstavljalo udruženje „Jefimijin vez“ sa sloganom: „Kao zlatnim koncem sa ljubavlju vezemo Jefimiji u čast“. Trstenički kraj je takođe poznat i po ćilimima. Još je čuveni putopisac Feliks Kanic primetio da nigde u Srbiji nema tako kvalitetnih ćilima kao što ih imaju Pirot i Trstenik. Veštine tkanja i veza se neguju u pomenutim udruženjima. Opština Trstenik je poznata po svom bogatom folklornom nasleđu i zalaganju Turističke organizacije da kroz aktivnu promociju oživi stare zanate i narodno stvaralaštvo (Turistička organizacija Srbije, Turistička organizacija opštine Trstenik, 2009).

\section{ZAKLJUČAK}

Prirodne karakteristike područja opštine Trstenik se mogu oceniti kao izrazito povoljne sa ruralnim prostorom velike koncentracije prirodnih resursa kao što su poljoprivredno zemljište, 
šume, vode i očuvani ekosistemi. Bogatstvo kulturnih resursa, kao i očuvana tradicija naroda koji žive na ovom prostoru, predstavlja jednu od prednosti ovih oblasti. Jedan od ključnih problema sa kojim se suočava ova opština, koji onemogućava njen razvoj je i demografski pad, negativan prirodni priraštaj, odliv stanovnika i napuštanje sela. Zaustavljanje depopulacije i suzbijanje ovog problema opština treba tražiti i u razvoju seoskog turizma čija prirodna bogatstva, društveno, kulturno i tradicionalno nasleđe takođe ima ulogu u formiranju identiteta i privlačnosti za turiste. Potrebno je ulagati u ovu oblast, ohrabrivati i obučavati stanovnike za bavljenje seoskim turizmom i motivisati ih da ostanu na svojim ognjištima i da se vrate tradiciji, omoguće posetiocima da dožive kombinaciju prirode, kulture i ljudi, da uživaju u autentičnim, originalnim iskustvima i vraćanju svojim korenima.

\section{LITERATURA}

Bošković, T. (2012). Ekonomski efekti razvoja turizma u ruralnim područjima Srbije. Škola biznisa. Novi Sad: Visoka poslovna škola strukovnih studija

Vukčević, M. (2009). Pla/pra sredstvo u okviru projekta mreža za podršku ruralnom razvoju. Mreža za podršku ruralnom razvoju Srbije. Beograd: Ministarstvo poljoprivrede, šumarstva i vodoprivrede.
Medlik, S. (1966). Economic Importance of Tourism. Univercity of Surrey, London. The Tourist Review, p. 39.

Ministarstvo trgovine, turizma i telekomunikacija. (2006). Strategija razvoja turizma Republike Srbije. Pristupljeno 16.1.2015. http://mtt.gov.rs/download/Strategija\%20razvoja\%20 turizma,cir.pdf

Ministarstvo građevinarstva, saobraćaja i infrastrukture. (2010). Zakon o prostornom planu RS od 2010 do 2020. godine. Pristupljeno 23.1.2015. http://www.mgsi.gov.rs/sites/default/ files/ZAKON\%20O\%20PROSTORNOM\%20PLANU\%20 RS\%20OD\%202010\%20DO\%202020.pdf

Republički zavod za statistiku. (2013). Demografska statistika u Republici Srbiji, 2013. Pristupljeno 12.1.2015. www.stat. gov.rs

Regionalni centar za životnu sredinu za centralnu i istočnu Evropu. (2010). Lokalni akcioni plan opštine Trstenik. Pristupljeno 23.1.2015. www.trstenik.rs

Turistička organizacija Srbije, Turistička organizacija opštine Trstenik. (2009). Vodič kroz opštinu Trstenik, Mirjana Glidžić. Trstenik

UNWTO and Tourism \& Leisure Advisory Services. (2011). Program razvoja održivog ruralnog turizma u Republici Srbiji. Pristupljeno 24.1.2015. http://ruralniturizamsrbija.com/ download/master-plan-program-razvoja-izvod.pdf 